\title{
Odnos starejših ljudi do dóma in domačega bivalnega okolja
}

Stanovanje spada med osnovne človekove dobrine in pravice. Njegova vloga je mnogostranska, saj omogoča zadovoljevanje številnih človekovih potreb, poleg tega stanovanje ni omejeno le na ozek bivalni prostor, ampak vključuje tudi širše bivalno okolje, v katerem posameznik prebiva. Odnos posameznika do stanovanja in bivalnega okolja se skozi njegovo življenje spreminja. Zlasti v času starosti naj bi dobilo stanovanje še poseben pomen. Kot kažejo raziskave, želijo starejši zato čim dalj časa ostati v svojem bivalnem okolju, saj naj bi bili nanj navezani. Da bi ugotovili, ali spoznanja o navezanosti starejših na lastno bivalno okolje držijo tudi za Slovenijo, smo v članku analizirali, koliko so na svoje stanovanje in širše bivalno okolje navezani starejši v Sloveniji in kako so z bivanjem v njem zadovoljni. Mnenja starejših smo pridobili z anketiranjem, statistično analizo pa smo opravili s programom SPSS, in sicer na podlagi izračuna več statističnih testov povezanosti. Analiza je potrdila našo predpostavko, da so tudi slovenski starejši na svoj dom oziroma domače okolje zelo navezani in da so z bivanjem v njem zadovoljni. Pokazalo se je še, da so med starejšimi glede tega nekatere razlike, ki so odvisne od tega, koliko so ljudje stari, kje živijo in koliko časa že bivajo v svojem domu.

Ključne besede: staranje prebivalstva, stanovanje, bivalno okolje, zadovoljstvo, navezanost, staranje v domačem okolju 


\section{Uvod}

Pravico do stanovanja štejemo med temeljne človekove pravice. Kot navaja Scott Leckie (1994), je ustrezno, cenovno dosegljivo in dostopno stanovanje splošno priznano kot temeljna sestavina življenja v miru, dostojanstvu in varnosti. Po Srni Mandič (2011) spada stanovanje nedvomno med najpomembnejše dejavnike kakovosti življenja in blaginje ljudi, kar je priznano tako v družboslovnih vedah (glej na primer Erikson, 1993; Atkinson idr., 2002; Fahey idr., 2004; Domanski idr., 2006; Daly, 2007) kot $v$ številnih mednarodnih političnih dokumentih, na kar opozarjajo mnogi avtorji (glej na primer Barlow in Duncan, 1994; Kleinman idr., 1998, 2013; Doling, 1999, 2006; Milligan, 2003; Czischke in Gruis, 2007). Tudi vloga stanovanja v blaginji ljudi je zelo mnogostranska. Stanovanje namreč obsega številne značilnosti, tako fizične (velikost, opremljenost z infrastrukturo ipd.) kot druge, težje merljive (lokacija, dostop do storitev, prijateljske vezi v soseščini ipd.) (Mandič, 1996). Bivalno okolje namreč ni omejeno le na stanovanjsko enoto, ampak tudi na ožjo in širšo stanovanjsko skupnost. Po Björnu Hårsmanu in Johnu M. Quigleyju (1991) ima zato stanovanje status najkompleksnejše dobrine, zaradi česar je nemogoče zajeti vse njegove pomene $\mathrm{v}$ odnosu do posameznika, ugotavlja Mandičeva (2011). Na to je opozoril že Peter Marcuse (1987: 232) s svojo opredelitvijo, da je »stanovanje več kot stanovanje « (ang. housing is more than just housing).

Stanovanje omogoča zadovoljevanje fizičnih, psiholoških in socialnih potreb, kar Mandičeva (1996) aplicira na Allardtovo trihonomno razvrstitev potreb (glej Allardt, 1993) imeti - ljubiti - biti, in sicer (a) imeti zajema značilnosti stanovanja, ki določajo kakovost stanovanja kot materialnega vira; gre za stanovanjski standard in te značilnosti omogočajo zadovoljevanje bioloških potreb; (b) ljubiti pomeni, da stanovanje zadovoljuje človekovo potrebo po družabnih stikih, partnerskih odnosih, ustanavljanju samostojnega gospodinjstva in družine, vključitvi v lokalno skupnost ipd., (c) biti pomeni, da stanovanje zadovoljuje potrebo po samouresničevanju in izkazovanju osebne identitete posameznika in njegovega izpopolnjevanja; $s$ to potrebo je povezana simbolna funkcija stanovanja, saj stanovanje z videzom, lokacijo ipd. izraža posameznikov ugled $\mathrm{v}$ družbi. Stanovanje je torej »fizični in socialni prostor, ki ga posameznik obvladuje, v katerem izraža svojo osebno identiteto, zasebnost in varnost « (Saunders, 1990: 39). Potreba po varnosti se pri tem nanaša na »ontološki občutek varnosti, na prostor, v katerem se človek počuti varnega « (Boškić, 2002: 21). Gre za eno izmed tistih človekovih potreb, ki je izrednega pomena za delovanje v družbi. Po drugi strani je potreba po zasebnosti povezana z zadovoljevanjem primarnih potreb. Stanovanje kot prostor zasebnega umika omogoča oblikovanje občutij doma. Stanovanje kot tako, torej kot dom, je v individualni opredelitvi ljudi središče družinskega življenja, svobode, neodvisnosti, individualnosti, samoizražanja in socialnega statusa ter je podpora za delo in prostočasne dejavnosti (Somerville, 1997). Po Petru Saundersu in Petru Williamsu (1988) zmanjšuje občutek odtujenosti, nemoči in fatalizma v sodobni družbi.

Odnos posameznika do stanovanja oziroma doma se skozi njegovo življenje spreminja. Še zlasti velik pomen dobi c človekovi starosti (Mandič, 2011). Po Frances Heywood idr. (2002) starejši ljudje stanovanje ali dom povezujejo s številnimi spomini in identiteto, po Anni Dupuis in Davidu Thornsu (1996) s tem, kaj so v življenju dosegli, po Rogerju Cloughu idr. (2004) pa tudi z mrežo družbenih vezi, ki so jo stkali v okolju, v katerem prebivajo. Kot navajata Ivan Śtuhec in Maksimiljan Fras (2010), je torej življenje starejših osrediščeno okoli stanovanja in bližnje okolice, kar kaže, da so starejši na svoje domače bivalno okolje zelo navezani. Da bi ugotovili, ali spoznanja o navezanosti starejših na lastno bivalno okolje držijo tudi za Slovenijo, bomo analizirali del rezultatov raziskave, ki smo jo opravili v okviru projekta Inovativne oblike bivalnih okolij za starejše v Sloveniji. Zanima nas, koliko so na svoje stanovanje in širše bivalno okolje navezani starejši v Sloveniji in kako so z bivanjem v njem zadovoljni. Predvidevamo, da so tako kot v drugih državah tudi v Sloveniji starejši ljudje na svoj dom oziroma domače okolje zelo navezani in da so $\mathrm{z}$ bivanjem $\mathrm{v}$ njem zadovoljni. Sklepamo, da so med starejšimi glede tega nekatere razlike, in sicer glede na različne starostne skupine oziroma starost stareǰ̌ih, različna okolja, v katerih živijo (mesto ali podeželje), lastništvo (last ali najem), vrsto stanovanjske enote, v kateri bivajo (hiša ali stanovanje), in trajanje bivanja v njej.

\section{Teoretična izhodišča}

Po najširši opredelitvi naj bi bila navezanost na dom čustvena vez med posameznikom in njegovim okoljem (Jorgenson in Stedman, 2001; Brown in Raymond, 2007). Ker je to pojmovanje zelo široko, raziskovalci razčlenijo navezanost na dom na odvisnost od prostora (Williams in Vaske, 2003), navezanost na sosesko (Sampson, 1988), prostorsko identiteto (Williams idr., 1992), družbene vezi (Kyl idr., 2005), zakoreninjenost (Tuan, 1980; Hay, 1998;), genealoško in ekonomsko navezanost (Mishra idr., 2010) in čustveno navezanost (Kyle idr., 2010). Različni avtorji se ukvarjajo tudi s tem, kaj pomeni navezanost na dom v metodološkem smislu (glej na primer Trentelman, 2009; Lewicka, 2011; Hernandez idr., 2013), še zlasti, če želimo izmeriti njeno intenzivnost. Ta je po mnenju nekaterih (glej na primer Shamai, 1991; Lalli, 1992; Williams idr., 1992; Moore in Graefe, 1994; Bricker in Kerstetter, 2000; Kyle idr., 2005) odvisna predvsem od obsega in količine stika, ki ga ima posameznik z bivalnim okoljem. 
Kot navajata Charis E. Anton in Carmen Lawrence (2014), ima lahko pri navezanosti na dom stopnja njene intenzivnosti pozitivne in negativne učinke. $\mathrm{Na}$ eni strani naj bi bila velika navezanost povezana z dobrim zdravjem in vključitvijo v skupnost. Posamezniki, ki so bolj navezani na svoje stanovanje in okolico, poročajo o večji družbeni vključitvi v lokalno skupnost (Mesch in Manor, 1998), kar ima močan vpliv na razvoj skupnosti. Navezanost na dom lahko tudi izboljša kakovost življenja (Harris idr., 1995) ter psihično in fizično zdravstveno stanje, vpliva na bolǰ̌e družbene vezi in na splošno zadovoljstvo s širšim bivalnim okoljem (Tartaglia, 2012). Posamezniki, ki ne razvijejo navezanosti na svoj dom ali pri katerih je ta navezanost zelo šibka, pa poročajo o višjih ravneh stresa in slabšem zdravstvenem stanju (Stokols in Shumaker, 1982). Negativno lahko deluje tudi močna navezanost na dom, še zlasti pri starejših, kot to navaja Mark Fried (2000). (Pre)močna navezanost na dom namreč starejše pogosto ovira pri tem, da bi se v primeru poslabšanega zdravstvenega stanja in v drugih okoliščinah, ko njihovo bivalno okolje ni več primerno za bivanje, preselili v primernejše bivalno okolje, ki bi izboljšalo kakovost njihovega življenja. Premočna navezanost se lahko kaže tudi v pretiranem zadrževanju v stanovanju in zmanjšanju družbenih stikov, kar lahko vodi do izolacije. Skrb vzbuja ugotovitev Štuheca in Frasa (2010), da slovenski starostniki v povprečju zunaj svojega doma preživijo le 2,5 ure dnevno.

Da so starejši na svoje domače bivalno okolje intenzivno navezani in želijo v njem ostati čim dalj časa, potrjujejo tudi številne raziskave, med katerimi izstopa predvsem anketa, ki jo je leta 2005 opravilo ameriško združenje za upokojence (ang. American Association of Retired People, glej Salomon, 2010). Po njihovih podatkih je 89 \% ljudi, starejših od 50 let, izjavilo, da želijo ostati v svojem domu, kolikor je mogoče dolgo in ohraniti svojo neodvisnost. Še podrobnejša raziskava omenjenega združenja je pokazala, da se delež ljudi, ki imajo takšne želje, s starostjo povečuje (Salomon, 2000). Med starostniki želi v svojem stanovanju ostati tako dolgo, kot bo mogoče, $75 \%$ starih med 45 in 54 let, $83 \%$ starih med 55 in 64 let, $92 \%$ starih med 65 in 74 let in kar $95 \%$ starih 75 ali več let. Če ne bi bili več zmožni živeti samostojno, si starejši po Emily Salomon (2010) še vedno zelo želijo ostati in bivati v svoji skupnosti oziroma soseski, znanem bivalnem in družbenem okolju. Po raziskavi ameriškega združenja za upokojence, na katero se avtorica sklicuje, je takšnih $85 \%$. Družbene povezave $s$ prijatelji in sosedi, poznavanje lokalnih možnosti za prijetno bivanje, bližina do storitev so po njenih ugotovitvah med številnimi prednostmi, ki bi jih starejši izgubili, če bi se morali preseliti. Zato starejši o preselitvi niti ne želijo razmišljati (glej na primer Kerbler, 2014). To potrjuje ugotovitev Petra de Jonga idr. (2012) glede navezanosti na stanovanje, in sicer da je prav ta pogosto navedena kot ena izmed glavnih razlogov za zelo majhno mobilnost starejših. Pri tem ima pomembno vlogo lastništvo stanovanja, kar za slovenski prostor potrjujejo tudi rezultati raziskave, ki so jo opravili Sendi idr. (2003). Večina tistih starejših, ki bi se preselili, je namreč živela v najemniškem stanovanju. Delež tistih, ki so živeli v lastniškem bivališču in bi se preselili, je bil precej manjši. Pomembnost te ugotovitve in dodatno utemeljitev za našo analizo glede navezanosti starejših na domače bivalno okolje lahko podkrepimo še s podatki raziskave SHARE o zdravju, staranju in upokojevanju v Evropi (glej Mandič, 2015), ki kažejo, da je med starejšim prebivalstvom v Sloveniji značilna izrazita prevlada lastniškega stanovanja nad najemnim (po velikem deležu lastniških stanovanj se slovenska starejša gospodinjstva uvrščajo na tretje mesto med vsemi državami v raziskavi SHARE). Iz tega torej lahko sklepamo, da so v Sloveniji starejši zelo navezani na domače bivalno okolje in da se zato ne želijo preseliti.

Poleg navezanosti na stanovanje naj bi bilo po Stephenu M. Golantu (1982) tudi zadovoljstvo z njim eden izmed dejavnikov morebitne selitve in stanovanjskih preferenc ter subjektivni kazalnik kakovosti življenja. Zadovoljstvo s stanovanjem je odvisno od različnih posameznikovih dejavnikov, kot so zdravstveno stanje in potencialna oviranost, stiki v soseski in varnost. Nanj vplivajo tudi lastnosti stanovanja, kot sta njegova kakovost in velikost, in subjektivna ocena varnosti v njem (Hwang idr., 1999). Pomemben je tudi individualni prostor, ki ga ima posameznik na voljo, kar vpliva na zdravje in $s$ tem posledično na zadovoljstvo (Costa-Font, 2013). Po mnenju Štuheca in Frasa (2010) je zadovoljstvo s stanovanjem ključno za kakovost življenja predvsem pri starejših. Kot namreč Štuhec in Fras (2010: 6) navajata, raziskave kažejo, da »starejši ljudje, ki so zadovoljni s svojim stanovanjem, pozitivneje načrtujejo prihodnost, so na telesnem, duševnem in socialnem področju aktivnejši, imajo več socialnih stikov in pozitivneje doživljajo vsakdan «. Kot najpomembnejši potrebi na področju bivanja in zadovoljstva z njim starejši po njunem mnenju navajajo potrebo po varnosti in neodvisnosti oziroma samostojnosti, po poročanju Paule Vasara (2015) pa tudi potrebo po miru, bližini narave ter dostopu do storitev in prostočasnih aktivnosti.

\section{Metode}

\subsection{Način pridobitve podatkov in značilnosti vzorca}

Podatke za analizo smo v okviru raziskave, navedene v uvo$\mathrm{du}$, pridobili $\mathrm{z}$ anketiranjem. Po našem naročilu ga je novembra 2015 izvedel Center za raziskovanje javnega mnenja in množičnih komunikacij, ki deluje v sklopu Inštituta za družbene vede pri Fakulteti za družbene vede Univerze v Ljubljani. Šlo je za telefonsko anketiranje, $s$ t. i. tehniko anketiranja 
CATI (ang. computer-assisted telephone interviewing), $\mathrm{v}$ katero je bilo vključeno prebivalstvo Slovenije, staro 50 let in več, obeh spolov, iz vseh statističnih regij in tipov naselij (mestnih in podeželskih). Končnih veljavnih anket je bilo 930, kar pomeni $0,11 \%$ vsega slovenskega prebivalstva v starosti 50 in več let.

Anketa je obsegala vprašanja, povezana $\mathrm{z}$ nepremičninami, gospodinjstvi, v katerih živijo anketiranci (lastništvo, velikost, čas bivanja $\mathrm{v}$ stanovanju ali hiši, težave, povezane $\mathrm{z}$ vzdrževanjem nepremičnine, prilagojenost nepremičnine za bivanje v starosti, število članov gospodinjstva, bližina sorodnikov ipd.), ter z ekonomskim stanjem in zdravjem anketiranih. Zanimali so nas še zadovoljstvo anketirancev $s$ stanovanjem ${ }^{[1]}$ in bivalnim okoljem, v katerem živijo, navezanost na ožje (stanovanje) in širše bivalno okolje (soseska oziroma okolje, v katerem živijo), stališče do morebitne preselitve, oblike pomoči, ki jih anketiranci prejemajo oziroma bi jih potrebovali za opravljanje nekaterih dejavnosti, in raznih bivalnih okolij za starejše $s$ poudarkom na oblikah bivanja, ki so v slovenskem okolju manj pogoste oziroma jih še ni, ter odnos do raznih stanovanjskih rešitev, ki omogočajo pridobitev dodatnih prihodkov iz lastništva nepremičnine. Na koncu so bila anketiranim zastavljena še vprašanja v zvezi z demografijo (starost, spol, izobrazba, status in kraj bivanja).

V preglednici 1 so predstavljene izbrane značilnosti vzorca, in sicer tiste, za katere želimo s statistično analizo preveriti, ali so med stareǰimi statistično pomembne razlike glede navezanosti na domače bivalno okolje in glede zadovoljstva z njim. Povprečna starost anketiranih je 69,3 leta, v domačem bivalnem okolju pa živijo v povprečju 36,5 leta. Med anketiranci, ki živijo na podeželju, jih 69,8 \% živi v strnjenem podeželskem naselju oziroma v njegovi bližini, $30,2 \%$ pa v razpršenem podeželskem naselju oziroma na samem. Med tistimi, ki živijo v mestnem okolju, jih 54,7 \% živi v manjšem, 45,3 \% pa v večjem mestu, od tega več kot polovica $(56,7 \%$ ) v Ljubljani oziroma Mariboru. Med lastniki hiš ali stanovanj, v katerih živijo anketiranci, jih 74,8 \% živi v hišah, $25,2 \%$ pa v stanovanju.

\subsection{Izbrane spremenljivke}

Za potrebe problematike, ki jo obravnavamo v tem članku, se bomo pri analizi osredotočili na vprašanja, povezana z zadovoljstvom in navezanostjo anketirancev na stanovanje oziroma bivalno okolje. Za ugotavljanje navezanosti nas bosta zanimali navezanost anketirancev na stanovanje in njihova navezanost na sosesko oziroma okolje, v katerem živijo. V nekaterih primerih bomo oba vidika navezanosti združili v splošno navezanost. Pri zadovoljstvu bomo poleg splošnega zadovoljstva ugotavljali, kako zadovoljni so anketiranci s stanovanjem, z okoljem,
Preglednica 1: Izbrane značilnosti anketirancev

\begin{tabular}{|c|c|c|}
\hline spremenljivke & razredi/skupine & delež (v \%) \\
\hline \multicolumn{3}{|l|}{ starost } \\
\hline & 50-59 let & 18,8 \\
\hline & 60-69 let & 32,5 \\
\hline & 70-79 let & 30,5 \\
\hline & 80 let in več & 18,3 \\
\hline \multicolumn{3}{|l|}{ tip naselja } \\
\hline & podeželje & 46,3 \\
\hline & mesto & 53,7 \\
\hline \multicolumn{3}{|c|}{ lastništvo stanovanja } \\
\hline & lastništvo & 97,9 \\
\hline & najem & 2,1 \\
\hline \multicolumn{3}{|c|}{$\begin{array}{l}\text { trajanje bivanja v domačem } \\
\text { bivalnem okolju }\end{array}$} \\
\hline & 10 let in manj & 6,2 \\
\hline & 11-20 let & 11,6 \\
\hline & 21-30 let & 18,6 \\
\hline & $31-40$ let & 28,0 \\
\hline & $41-50$ let & 20,4 \\
\hline & 51 let in več & 15,2 \\
\hline
\end{tabular}

v katerem živijo, s fizično dostopnostjo v bivalnem okolju ter $\mathrm{z}$ bližino storitev in oskrbe $\mathrm{v}$ njem.

Vsakega od navedenih štirih sklopov zadovoljstva smo že v anketi notranje razčlenili na posamezne vidike:

- v okviru zadovoljstva s stanovanjem nas je zanimalo, kako zadovoljni so z (a) razporeditvijo prostorov, (b) velikostjo in (c) gradbeno kakovostjo;

- v zvezi z okoljem, v katerem živijo, smo jih spraševali, kako zadovoljni so z (d) splošno urejenostjo okolja, (e) mirom v okolju, (f) kakovostjo zraka v stanovanjski okolici in (g) varnostjo v okolju;

- pri fizični dostopnosti smo se osredotočili na zadovoljstvo $s$ (h) zunanjo dostopnostjo oziroma dostopnostjo do objekta, v katerem bivajo (npr. promet, cesta, parkirišče), (i) notranjo dostopnostjo oziroma dostopnostjo do stanovanja (npr. dvigalo, stopnice oziroma druge arhitekturne ovire);

- pri četrtem sklopu pa so anketiranci izrazili svoje zadovoljstvo $\mathrm{z}(\mathrm{j})$ bližino sorodnikov in prijateljev, $(\mathrm{k})$ bližino zdravstvene oskrbe, (l) bližino storitev dolgotrajne oskrbe za starejše (npr. oskrba na domu), (m) možnostmi za rekreacijo in druženje v bližini doma in (n) bližino javnih servisov in storitev (npr. trgovina, pošta, avtobus).

Anketirance smo prosili, naj stopnjo zadovoljstva z (ožjim in širšim) bivalnim okoljem in navezanost nanj ocenijo na lestvici 
od ena do pet, pri čemer je ocena ena pomenila, da anketiranec sploh ni zadovoljen/navezan, dva, da ni zadovoljen/navezan, tri, da ni niti nezadovoljen/nenavezan niti zadovoljen/navezan, štiri, da je zadovoljen/navezan, in pet, da je zelo zadovoljen/navezan. Anketiranci so imeli možnost odgovoriti še z ne vem, lahko pa jim na vprašanje sploh ni bilo treba odgovoriti. Kot je razvidno iz preglednice 2, so anketiranci kljub tej možnosti v veliki večini podali svoje ocene.

\subsection{Predstavitev metod in postopkov za statistično analizo}

Čeprav je opisana petstopenjska lestvica ocenjevanja zadovoljstva z bivalnim okoljem in navezanosti nanj urejenostna (ordinalna), smo jo za potrebe statistične analize obravnavali kot razmernostno oziroma intervalno ${ }^{[2]}$, iz analize pa smo izključili tudi odgovore Ne vem in tiste anketirance, ki na neko vprašanje niso odgovorili. Statistično analizo smo opravili s programom SPSS za Windows 23.0. Poleg osnovnih statističnih izračunov (deleži in povprečja) smo za to, da bi dobili odgovore na zastavljena raziskovalna vprašanja ter da bi preverili svoje sklepe in predpostavke, izračunali različne statistične teste. $\mathrm{Da}$ bi ugotovili, ali se povprečna vrednost izbrane spremenljivke razlikuje med dvema skupinama enot, smo uporabili $t$-test za neodvisna vzorca, v primeru več kot dveh skupin pa analizo variance. Pri zadnjenavedeni smo za ugotavljanje statistično značilnih razlik v povprečju določene spremenljivke izbrali različne postopke, odvisno od velikosti skupin in izpolnitve predpostavke o enakosti varianc. Pri tem smo sledili smernicam Andyja Fielda (2009) in uporabili postopek REGWQ ali Tukeyjev HSD, če so skupine enako velike, Gabrielov postopek, če se velikosti skupin nekoliko razlikujejo, postopek Hochberg's GT2 pa, če so velikosti skupin zelo različne. V vseh primerih mora biti izpolnjen pogoj o homogenosti varianc med skupinami. Če predpostavka o enakosti varianc ni bila izpolnjena, smo uporabili Games-Howellov postopek, pred tem pa smo test enakosti povprečij med spremenljivkami namesto $\mathrm{z}$ analizo variance opravili z robustnima testoma Brown-Forsythe in Welch. Povezanost med imenskima (nominalnima) spremenljivkama smo preverjali s Pearsonovim hi-kvadrat $\left(\chi^{2}\right)$ testom, $\mathrm{v}$ primeru ugotovljenih povezav pa smo intenzivnost oziroma stopnjo povezanosti obeh spremenljivk ugotavljali s koeficientom kontingence $C$ oziroma s Cramerjevim $V$. Izračunov Pearsonovega koeficienta korelacije $(r)$ smo se lotili v primeru ugotavljanja povezanosti dveh razmernostnih oziroma intervalnih spremenljivk. Povprečne vrednosti smo v članku prikazovali z oznako $M$, statistične razlike $(p)$ pa smo obravnavali kot pomembne pri eno- ali petodstotni stopnji tveganja. Zaradi večje preglednosti so prikazani samo končni rezultati, in sicer le tisti, ki so statistično pomembni.

\section{Rezultati in razprava}

Vasara (2015) ugotavlja, da so starejši na splošno zelo zadovoljni s svojim stanovanjem, kar potrjujejo tudi rezultati anketiranja. Vprašani so namreč izrazili, da so zelo zadovoljni z ožjim in širšim bivalnim okoljem in da so nanj zelo navezani - povprečna ocena zadovoljstva vseh vidikov stanovanja in bivalnega okolja je namreč 4,14, povprečna ocena navezanosti na stanovanje in okolje, v katerem starejši živijo, pa je še višja, in sicer 4,31. Kot je razvidno iz preglednice 2, so anketiranci med vsemi ocenjenimi vidiki navezanosti in zadovoljstva najvišje ocene dodelili navezanosti na stanovanje, čeprav so z vidiki stanovanja (razporeditev prostorov, velikost, gradbena kakovost) v primerjavi z drugimi manj zadovoljni - povprečna ocena je celo pod skupnim povprečjem zadovoljstva in znaša 4,07 , najmanj pri gradbeni kakovosti. Ob tem so starejši najvišje ocene pri zadovoljstvu dodelili vidikom, povezanim z okoljem, v katerem živijo $(M=4,24)$, čeprav so v primerjavi s stanovanjem na okolje manj navezani. To Anton in Lawrence (2014) pojasnjujeta s tem, da ima stanovanje bolj jasno opredeljene prostore, meje, soseska oziroma okolica pa je manj jasen koncept. Med vsemi vidiki zadovoljstva z okoljem najbolj izstopata zadovoljstvo z varnostjo v njem in mirom. Poleg okolja so starejši nadpovprečno zadovoljni tudi $s$ fizično dostopnostjo $(M=$ 4,22), precej bolj z dostopnostjo v širšem bivalnem okolju kot dostopnostjo do stanovanja. Najmanj so zadovoljni z bližino storitev in oskrbo v njem $(M=4,06)$ - vsi vidiki tega sklopa imajo podpovprečno oceno zadovoljstva. Najnižjo med vsemi dosega dostopnost do storitev dolgotrajne oskrbe, vendar je treba pri tem vidiku omeniti, da je bilo število odgovorov pri tem najmanjšs - skoraj $18 \%$ anketiranih namreč tega vidika ni ocenilo. Večji delež anket brez odgovorov oziroma z odgovorom Ne vem $(7,3 \%)$ je še pri možnosti za rekreacijo in druženje $\mathrm{v}$ bližini doma. Tudi $s$ tem vidikom so starejši podpovprečno zadovoljni.

Čeprav imata vidika navezanosti najvišji povprečni oceni in največji delež ocen pet - navezanost na stanovanje je s pet ocenilo $63 \%$ vprašanih, navezanost na okolje, v katerem starejši bivajo, pa 50,5\% (glej preglednico 2) -, sta glede na seštevek deležev ocen štiri in pet ter glede na razvrstitev vseh vidikov navezanosti in zadovoljstva (teh je šestnajst) šele na petem (navezanost na stanovanje) oziroma dvanajstem mestu (navezanost na okolje). Najvišji mesti pri tem zavzemata zadovoljstvo $\mathrm{z}$ varnostjo $\mathrm{v}$ okolju in zadovoljstvo $\mathrm{z}$ zunanjo fizično dostopnostjo. Prvi vidik je z ocenama štiri in pet ocenilo $90,3 \%$ starejših, drugega $89,1 \%$. Na tretjem mestu je zadovoljstvo z mirom s 85,1-odstotnim deležem odgovorov štiri in pet. Najnižja mesta dosegajo vidiki, katerih povprečne ocene zadovoljstva so prav tako najnižje, in sicer dostop do storitev dolgotrajne oskrbe (77,6\%), možnost za rekreacijo in druženje $(77,1 \%)$ in gradbena kakovost stanovanja $(74,3 \%)$. 
Preglednica 2: Povprečna ocena in delež ocen štiri oziroma pet ter delež teh dveh ocen skupaj po posameznih vidikih navezanosti in zadovoljstva

\begin{tabular}{|c|c|c|c|c|c|c|}
\hline sklop & vidik & $\begin{array}{l}\text { povprečna } \\
\text { ocena (M) }\end{array}$ & $\begin{array}{l}\text { delež ocen } \\
\text { štiri (v \%) }\end{array}$ & $\begin{array}{l}\text { delež ocen } \\
\text { pet }(\mathrm{v} \%)\end{array}$ & $\begin{array}{l}\text { delež skupaj } \\
(\mathrm{v} \%)\end{array}$ & razvrstitev* \\
\hline \multicolumn{7}{|c|}{ navezanost } \\
\hline & navezanost na stanovanje & 4,41 & 21,5 & 63,0 & 84,5 & 5 \\
\hline & navezanost na okolje & 4,21 & 28,3 & 50,5 & 78,8 & 12 \\
\hline \multicolumn{7}{|c|}{ zadovoljstvo } \\
\hline \multicolumn{7}{|c|}{ s stanovanjem } \\
\hline & razporeditev prostorov & 4,16 & 42,1 & 40,2 & 82,3 & 6 \\
\hline & velikost stanovanja & 4,10 & 39,3 & 40,5 & 79,8 & 10 \\
\hline & gradbena kakovost & 3,96 & 44,3 & 30,0 & 74,3 & 16 \\
\hline \multicolumn{7}{|c|}{ z okoljem } \\
\hline & urejenost okolja & 4,18 & 47,1 & 37,6 & 84,7 & 4 \\
\hline & mir v okolju & 4,28 & 37,1 & 48,8 & 85,9 & 3 \\
\hline & kakovost zraka & 4,14 & 37,1 & 42,2 & 79,3 & 11 \\
\hline & varnost & 4,35 & 43,5 & 46,8 & 90,3 & 1 \\
\hline \multicolumn{7}{|c|}{ z dostopnostjo } \\
\hline & dostop do objekta & 4,33 & 40,3 & 48,8 & 89,1 & 2 \\
\hline & dostop do stanovanja & 4,10 & 43,0 & 38,1 & 81,1 & 8 \\
\hline \multicolumn{7}{|c|}{ z bližino storitev in oskrbe } \\
\hline & bližina sorodnikov/prijateljev & 4,14 & 43,2 & 38,5 & 81,7 & 7 \\
\hline & bližina zdravstvene oskrbe & 4,10 & 44,8 & 35,7 & 80,5 & 9 \\
\hline & bližina storitev dolgotrajne oskrbe & 3,96 & 51,6 & 26,0 & 77,6 & 14 \\
\hline & možnost rekreacije/druženja & 4,01 & 42,8 & 34,3 & 77,1 & 15 \\
\hline & bližina javnih servisov/storitev & 4,10 & 36,5 & 41,3 & 77,8 & 13 \\
\hline
\end{tabular}

Opomba: * Razvrstitev glede na skupni delež ocen štiri in pet (1 pomeni najvišje, 16 pa najnižje mesto).

Čeprav je le majhen delež tistih, ki so svoje zadovoljstvo s posameznimi vidiki stanovanja in bivalnega okolja ter navezanost nanju ocenili z nižjimi ocenami, bomo poskušali v nadaljevanju ugotoviti, ali so med njimi in tistimi, ki so izrazili večje zadovoljstvo in navezanost, razlike v starosti, tipu naselja, $\mathrm{v}$ katerem živijo, lastništvu stanovanja in trajanju bivanja v njem ter (če te razlike so) ali se po teh razlikah med seboj statistično pomembno razlikujejo.

\subsection{Starost}

Že raziskava ameriškega združenja za upokojence, ki smo jo predstavili v teoretičnem delu članka, kaže, da se delež tistih, ki bi radi ostali čim dalj časa v svojem domu, s starostjo povečuje. Meredith Driscoll (2011) navaja, da mnogi raziskovalci (na primer Rubenstein, 1989; Fogel, 1992; Rowles in Ravdal, 2002) to željo starejših pripisujejo njihovi navezanosti na dom. Kot smo že navedli v uvodu in to potrjujejo tudi Duncan Case (1996), Hans-Werner Wahl (2003) ter Wahl in Laura N. Gitlin (2003), se s tem, ko se človek stara, pomen doma zanj povečuje, obenem pa tudi navezanost nanj.
$S$ staranjem ljudje vedno bolj čutijo, da so del okolja, v katerem živijo, da mu pripadajo, da je dom del njih, kar potrjuje tudi Graham D. Rowles (1983). Tudi po njegovem mnenju namreč starejši razvijejo poseben odnos do stanovanja, kar privede do tega, da se z njim identificirajo in ga razumejo kot podaljšek sebe. Driscollova (2011) v zvezi s tem izpostavlja raziskavo Chrisa Gillearda idr. (2007), v kateri so angleški sedemdesetletniki in osemdesetletniki izkazali močnejšo navezanost na dom in skupnost $\mathrm{v}$ primerjavi $\mathrm{z}$ mlajšimi. Te ugotovitve lahko potrdimo tudi z našo raziskavo. Statistična analiza namreč kaže, da obstaja povezanost med starostjo anketiranih in splošno navezanostjo $(r=0,122 ; p=0,000)$. Kaže tudi povezanost $\mathrm{z}$ zadovoljstvom $(r=-0,084 ; p=0,012)$. Povezanost je resda $\mathrm{v}$ obeh primerih šibka, vendar je statistično pomembna pri enoodstotnem oziroma petodstotnem tveganju. Povezanost med starostjo in splošno navezanostjo je (po pričakovanjih) pozitivna, med starostjo in splošnim zadovoljstvom pa negativna. To pomeni, da se navezanost na domače bivalno okolje $s$ starostjo povečuje, zadovoljstvo z njim pa se zmanjšuje. Ta ugotovitev je razumljiva, saj se s starostjo pri ljudeh zmanjšuje mobilnost, zaradi česar imajo lahko težave pri dostopnosti do 
svojega doma in $\mathrm{v}$ širšem bivalnem okolju. Težave se lahko kažejo tudi z omejeno mobilnostjo v lastnem stanovanju, če ga arhitekturno ustrezno ne prilagodijo. $V$ starejših letih si ljudje želijo tudi več miru in varnosti, saj se počutijo bolj ogroženi in ranljivi. $S$ staranjem postopoma izgubljajo še svoje bližnje prijatelje, ki umrejo, zaradi zmanjšane mobilnosti pa pogosto tudi vse manj vzdržujejo družbene stike z ljudmi v svoji okolici. Velika težava je lahko tudi oddaljenost od javnih storitev.

Podrobnejša analiza navezanosti kaže, da so starejši anketiranci nekoliko bolj navezani na stanovanje $(r=0,130 ; p=0,000)$ kakor na okolje $(r=0,095 ; p=0,004)$, kar potrjujejo tudi spoznanja Carmen Hidalgo in Bernarda Hernande (2001) ter Marie Lewicke (2005). Tisti, ki so izrazili, da so zelo navezani na stanovanje, so v povprečju več kot deset let starejši $(69,9$ leta) kakor tisti, ki so navezanost na stanovanje ocenili z najnižjo oceno (59,5 leta). Da na stanovanje sploh niso navezani, so namreč navedli le tisti, ki so stari med 50 in 69 let. Pri navezanosti na okolje je med tema skupinama razlika v povprečni starosti nižja, vendar še vedno znaša 5,2 leta (ocena ena $=64,8$ leta, ocena pet $=70$ let).

Podrobnejša statistična analiza povezanosti med starostjo in posameznimi vidiki zadovoljstva s stanovanjem in okoljem, $\mathrm{v}$ katerem starejši bivajo, kaže, da je povezanost $\mathrm{v}$ vseh primerih negativna. Šibka, vendar statistično pomembna je pri zadovoljstvu z mirom v okolju $(r=-0,095 ; p=0,004), \mathrm{z}$ varnostjo $(r=-0,092 ; p=0,006)$, z dostopnostjo do stanovanja $(r=-0,106 ; p=0,002)$, z možnostjo za rekreacijo in druženje $(r=-0,069 ; p=0,044)$. Na stopnji desetodstotnega tveganja se povezanost kaže tudi v primeru zadovoljstva z zunanjo fizično dostopnostjo $(r=-0,055 ; p=0,099)$ in z bližino sorodnikov in prijateljev $(r=-0,058 ; p=0,083)$. Največja razlika v povprečni starosti je pri zadovoljstvu z varnostjo, saj znaša 68,3 leta pri tistih, ki z njo sploh niso zadovoljni, in 85,3 leta pri tistih, ki so z njo zelo zadovoljni. Pri zadovoljstvu z dostopnostjo do stanovanja znaša razlika 5,9 leta, pri zadovoljstvu z mirom v okolju pa 3,3 leta.

\subsection{Trajanje bivanja $v$ domačem bivalnem okolju}

Nekatere študije, na primer raziskava Chiare Rollero in Norme De Picolli (2010), povezave med starostjo in navezanostjo na bivalno okolje niso potrdile. Graham D. Rowles (1983) pojasnjuje to s tem, da so morda razlike med starejšimi, ki so v svojem življenju živeli na več lokacijah, in starejšimi, ki (še vedno) živijo v kraju rojstva. Domnevo potrjuje Robert Hay (1998), ki dokaže, da so res razlike v navezanosti med posamezniki, ki živijo v kraju rojstva (ti so bolj navezani), in posamezniki, ki so se v neki kraj preselili pozneje v življenju (ti so manj navezani). Na podlagi teh ugotovitev smo navezanost in zadovoljstvo opredelili tudi v odnosu $s$ trajanjem bivanja starejšsi v domačem okolju. Poleg že omenjenih raziskav tudi druge študije (na primer Riger in Lavrakas, 1981; Sampson, 1988; Bonaiuto idr. 1999; Hidalgo in Hernandez, 2001; Lewicka, 2010) kažejo, da so starejši ljudje bolj navezani na stanovanje kot mladi, kar je povezano s časom, ki so ga preživeli v nekem stanovanju oziroma širšem bivalnem okolju. Tudi avtorji, kot so Stephen McCool in Steven Martin (1994), Marino Bonaiuto idr. (1999), Maria Lewicka (2005, 2010), Richard Stedman (2006), Christopher Raymond idr. (2010), so ugotovili povezanost med trajanjem bivanja v domačem bivalnem okolju in navezanostjo.

Po pričakovanju lahko tudi za našo raziskavo potrdimo, da obstaja povezanost med trajanjem bivanja $\mathrm{v}$ stanovanju in navezanostjo na bivalno okolje $(r=0,166 ; p=0,000)$. Razlika v višini linearne povezanosti pri navezanosti na stanovanje oziroma navezanosti na okolje, v katerem starejši bivajo, je zanemarljiva. Povezanost je v obeh primerih pozitivna in statistično pomembna pri enoodstotnem tveganju, kar pomeni, da se $s$ trajanjem bivanja v domačem bivalnem okolju povečuje tudi navezanost nanj. Povprečno trajanje bivanja tistih, ki so svojo navezanost na stanovanje ocenili z ena, je 21,7 leta, pri tistih, ki so jo ocenili s pet, pa se podaljša za 16,2 leta in znaša 37,9 leta. Pri navezanosti na okolje je ta razlika še večja, in sicer 18,7 leta. Statistično pomembne razlike $\mathrm{v}$ trajanju bivanja $\mathrm{v}$ domačem okolju in navezanostjo nanj se kažejo tudi, če združimo v eno skupino tiste, ki so navezanost na stanovanje oziroma okolje ocenili z ena ali dva, v drugo pa tiste, ki so jo ocenili s štiri oziroma pet (vseh, ki so jo ocenili s tri, pri analizi ne upoštevamo). Oba $t$-testa (navezanost na stanovanje: $t(769)=-3,036$, $p=0,002$; navezanost na okolje: $t(811)=-3,265, p=0,001$ ) kažeta, da so med skupinama glede povprečnega trajanja bivanja razlike pri enoodstotnem tveganju, in sicer je razlika pri navezanosti na stanovanje 7,5 leta, pri navezanosti na okolje pa 6,3 leta.

Pri zadovoljstvu z bivalnim okoljem se je v odnosu s trajanjem bivanja pokazala povezanost le pri zadovoljstvu z gradbeno kakovostjo $(r=-0,101 ; p=0,002)$ in mirom v okolju $(r=-0,111 ; p=0,001)$. V obeh primerih je povezanost negativna, kar pomeni, da so tisti, ki bivajo v svojem stanovanju manj časa, z njegovo gradbeno kakovostjo in mirom v okolju bolj zadovoljni v primerjavi s tistimi, ki bivajo tam že dalj časa. Tako je na primer povprečno trajanje bivanja tistih, ki so z mirom v okolju zelo zadovoljni, 35,2 leta, tistih, ki z njim sploh niso zadovoljni, pa 42,3 leta. Povezanost $s$ trajanjem bivanja se kaže tudi v odnosu do zadovoljstva $\mathrm{z}$ bližino sorodnikov in prijateljev, ki je pozitivna, vendar je povezanost statistično značilna na desetodstotni lestvici tveganja. Pri vseh drugih vidikih zadovoljstva med starejšimi glede na njihovo trajanje bivanja $\mathrm{v}$ domačem okolju ni bilo nobenih razlik. Ugotovljeno potrjujeta tudi Eigil Boll Hansen in Georg Gottaschalk (2006), ki 
menita, da podaljš̌vanje trajanja bivanja na isti lokaciji več let $\mathrm{v}$ posamezniku res vzbudi navezanost na stanovanje in bivalno okolje, obenem pa lahko tudi zasenči morebitne praktične nevšečnosti (na primer slab dostop, neprilagojenost itd.).

\subsection{Tip naselja}

Anton in Lawrence (2014) sta na študiju vzorca avstralske populacije ugotovila, da so bili posamezniki v podeželskih predelih države bolj navezani na stanovanje kot posamezniki $\mathrm{v}$ urbanih predelih. Lewicka (2005) je to podprla s trditvijo, da je navezanost linearno negativno povezana z velikostjo naselja; posamezniki v manjših krajih so torej bolj navezani na svoj dom kot posameznikiv večjih krajih oziroma mestih. Tudi primerjava splošne navezanosti starejših na lastno stanovanje in bivalno okolje v okviru naše raziskave kaže, da so statistično pomembne razlike med tistimi, ki bivajo v mestnih naseljih, in tistimi, ki bivajo na podeželju $(t(913,832)=3,363, p=0,001)$. Starejšì, ki bivajo na podeželju, so v splošnem bolj navezani na svoje domače okolje $(M=4,41)$ kot tisti, ki bivajo v mestnih naseljih $(M=4,22)$. Po mnenju Lewicke (2005) je to posledica tega, da so starejši v mestnih okoljih med seboj najverjetneje manj povezani oziroma imajo manj družbenih stikov in so vključeni $\mathrm{v}$ manj združenj, ki povezujejo ljudi, v primerjavi s tistimi, ki živijo $\mathrm{v}$ podeželskih območjih. Pri tem se avtorica sklicuje na enake ugotovitve drugih avtorjev, kot so John D. Kasarda in Morris Janowitz (1974), Robert J. Sampson (1988) ter Gene L. Theodori in A. E. Luloff (2000). Zadnjenavedena avtorja sta se glede razlik v navezanosti v podeželskih in mestnih območjih $\mathrm{v}$ svoji raziskavi oprla na spoznanja družbenih teoretikov iz poznega devetnajstega in začetka dvajsetega stoletja, po katerih se kaže čedalje večja zaskrbljenost zaradi povečevanja urbanizacije, modernizacije in industrializacije ter vpliva teh procesov na družbeno solidarnost in povezovanje ljudi v skupnosti. Zamisli teh teoretikov, med katerimi so bili najbolj prodorni Ferdinand Tönnies, Georg Simmel in Louis Wirth, smo poskušali aplicirati tudi na spoznanja v naši raziskavi. $V$ svojih spisih so namreč izpostavljali, da podeželske skupnosti v primerjavi z mestnim okoljem spodbujajo višjo stopnjo solidarnosti, vključevanja, zaradi česar so ljudje, ki živijo v teh skupnostih, bolj navezani na svoj prostor bivanja (glej Tönnies, 1887; Simmel, 1903; Wirth, 1938). Kot navajata Theodori in Luloff (2000), je na primer Ferdinand Tönnies (1887) v svojem idealnem pojmovanju družbene preobrazbe iz družbe (nem. Gemeinschaft) v skupnost (nem. Gesellschaft) trdil, da so procesi urbanizacije in industrializacije spremenili poglavitne značilnosti družbe iz skupnostne navezanosti na podlagi naravne volje v združevalno navezanost, ki temelji na racionalni volji. Simmel (1903) je to nadgradil s spoznanji, da na podeželju ritem življenja in senzorične zaznave ljudi potekajo počasneje, bolj naravno in umirjeno ter bolj enakomerno v primerjavi z mestnim načinom življenja. Po njegovem mnenju so zato ljudje, ki živijo v mestih, razvili otopel odnos do bivalnega prostora, in sicer zato, da se zaščitijo pred hitrimi spremembami v okolju in stresom ter da bi si s tem zagotovili samoohranitev. Iz njegove perspektive se lahko ta otopel odnos, ki se kaže v zadržani osebnosti posameznikov v mestnem okolju, izraža v izgubi navezanosti na skupnost in bivalni prostor. Kljub tej in drugim klasičnim pogledom urbanizacije je po mnenju Theodorija in Luloffa (2000) predvsem Wirthova teorija tista, ki opredeljuje, katere učinke ima mestno okolje na posameznike in njihovo medsebojno povezanost (glej Wirth, 1938, in Fischer, 1972; Christenson, 1979). Po Louisu Wirthu (1938) so namreč velikost (število prebivalstva), gostota (gostota poselitve) in heterogenost prebivalcev v mestih tiste značilnosti, ki povzročajo oslabitev sorodstvenih vezi, zamenjavo osnovnih stikov s sekundarnimi, zmanjšanje poudarka družbenega pomena lokalne skupnosti ter $v$ tem smislu poslabšanje in izgubo povezanosti s skupnostjo ter posledično nižjo stopnjo navezanosti na okolje, $\mathrm{v}$ katerem posameznik živi, v primerjavi s podeželjem (Wirth 1938; glej tudi Fischer, 1972, in Christenson, 1979).

Predstavljene ugotovitve družbenih teoretikov veljajo za vse prebivalstvo in s tem tudi za tisti del, ki ga obravnavamo v naši raziskavi, kar potrjujejo rezultati. Ti postavljajo pomen kraja bivanja pri navezanosti celo pred pomen, ki ga ima pri tem starost. In čeprav smo ugotovili, da se stopnja navezanosti z nižanjem starosti statistično pomembno znižuje in je povprečna starost vprašanih na podeželju $(M=67,5)$ statistično pomembno nižja $(t(901)=-4,964, p=0,000)$ od tistih v mestu $(M=$ $70,8)$, so, kot smo že o tem poročali, živeči na podeželju kljub temu izkazali večjo splošno navezanost na bivalno okolje od svojih vrstnikov v mestnih naseljih. Poleg splošne navezanosti starejših na lastno stanovanje in bivalno okolje v podeželskih in mestnih naseljih se statistično pomembne razlike kažejo tudi, če oba vidika navezanosti analiziramo ločeno - navezanost na stanovanje: $t(908,303)=2,696, p=0,007$, navezanost na okolje: $t(910)=3,350, p=0,001$. Poleg razlik je mogoče iz povprečnih ocen navezanosti razbrati še, da so starejši, ne glede na to, kje živijo, bolj navezani na stanovanje kot na svoje okolje. Povprečna ocena navezanosti na stanovanje je namreč višja tako na podeželju $(M=4,50)$ kot v mestu $(M=4,33)$, $\mathrm{v}$ primerjavi z navezanostjo na okolje - povprečna ocena navezanosti na podeželju je 4,33, v mestu pa 4,12. Ta ugotovitev delno izpodbija ugotovitve omenjenih družbenih teoretikov, kar kaže, da postaja tudi podežlje zelo raznovrsten prostor, ki je pod vplivom urbanizacije. Ta se kaže v krhanju nekdanje solidarnosti v podeželskih skupnostih, $v$ čedalje večji individualizaciji in posledično pogosto tudi v družbeni izključenosti starejših na podeželju (glej na primer Lichter in Brown, 2011; Walsh in Ward 2013).

V okviru zadovoljstva se starejši, ki živijo v podeželskih naseljih, in tisti, ki živijo v mestih, ne razlikujejo po vidikih 
stanovanja in vidikih, povezanih $s$ fizično dostopnostjo $\mathrm{v}$ okolju, razlikujejo pa se po zadovoljstvu z bližino storitev in oskrbe $(t(832,518)=-7,162, p=0,000)$ ter zadovoljstvu z okoljem, v katerem živijo $(t(917)=5,223, p=0,000)$. Vendar je to zadovoljstvo ravno obratno $-\mathrm{z}$ bližino storitev in oskrbe so bolj zadovoljni starejši prebivalci mestnih naselij $(M=$ $4,20)$ kakor starejši prebivalci podeželja $(M=3,90)$, z okoljem pa prebivalci podeželskih naselij $(M=4,35)$, manj pa meščani $(M=4,14)$. Pri ocenah zadovoljstva se v okviru zadnjenavedenega starejši na podeželju razlikujejo $s$ svojimi mestnimi vrstniki po zadovoljstvu z mirom v okolju $(t(917)=4,043$, $p=0,000)$, kakovostjo zraka $(t(915)=7,284, p=0,000)$ in varnostjo $(t(913)=3,568, p=0,000)$. Ne razlikujejo se le po zadovoljstvu s splošno urejenostjo okolja - glede tega so v obeh tipih naselij enako zadovoljni $(M=4,18)$. Kot je razvidno iz izračunanih $t$-testov, je med skupinama starejših v povprečni oceni zadovoljstva z okoljem največja razlika pri zadovoljstvu $s$ kakovostjo zraka - podeželani so ta vidik okolja ocenili s povprečno oceno 4,38, meščani s 3,95 -, na drugem mestu je zadovoljstvo z mirom v okolju - povprečje za podeželje je 4,41 za mesto pa 4,17 -, na tretjem pa zadovoljstvo $z$ varnostjo $-M=4,44$ oziroma $M=4,27$. Še bolj kakor z zadovoljstvom z okoljem se prebivalci podeželskih in mestnih naselij razlikujejo po zadovoljstvu z bližino storitev in oskrbe, in sicer po vseh štirih vidikih, ki jih ta sklop zadovoljstva vključuje. Povprečna ocena zadovoljstva vsakega izmed njih je v mestih nad štiri, na podeželju pa te povprečne ocene v nobenem primeru ne preseže. Največja razlika v izraženem zadovoljstvu je glede bližine javnih storitev in servisov $(t(824,283)=-9,258$, $p=0,000)$ - povprečna ocena v mestnih naseljih znaša 4,37, na podeželju pa 3,79. Precej različni so si v ocenah zadovoljstva tudi glede bližine zdravstvene oskrbe $(t(917)=-6,816$, $p=0,000)$ - to so na podeželju ocenili s povprečno oceno 3,90 , v mestih pa 4,28 - in z možnostjo za rekreacijo in druženje $(t(770,680)=-5,114, p=0,000)$, s povprečnima ocenama 4,16 in 3,82. Dostop do storitev dolgotrajne oskrbe $(t(684,749)=-5,732, p=0,000)$ je bil v mestih ocenjen $s$ povprečno oceno 4,14 na podeželju pa s 3,78. To je tudi najnižja povprečna ocena, ki so jo starejši na podeželju dodelili kateremu izmed vidikov zadovoljstva (v mestu je bila na primer najnižje ocenjena kakovost zraka s 3,95).

\subsection{Lastništvo stanovanja}

Saunders (1990: 39) navaja, da je lastno stanovanje »čustveni izraz avtonomije, varnosti in osebne identitete «, zato naj bi bili po njegovem mnenju lastniki v primerjavi z najemniki bolj čustveno navezani na stanovanje. Dodaja še, da je večini lastnikov stanovanje zadovoljstvo, $s$ tem, ko ga lahko vzdržujejo, zanj skrbijo in ga izboljšujejo. Z možnostjo urejanja doma po svojem okusu naj bi se po mnenju Georgea C. Galstra (1987) počutili bolj svobodni in avtonomni v primerjavi z najemniki, na takšen način urejen bivanjski prostor pa naj bi po avtorjevih besedah verjetno tudi bolj podpiral njihov življenjski cikel ter obenem povečal njihovo zadovoljstvo z bivanjem in življenjem na splošno. To potrjujeta Peter H. Rossi in Eleanora Weber (1996), ki sta dokazala statistično povezanost med lastništvom nepremičnin ter samozadovoljstvom in srečo. To je po navedbah Galstra (1987) še posebej značilno za starejše ljudi, ki naj bi bili v primerjavi z najemniki tudi bolj zadovoljni s svojo nepremičnino in okolico, v kateri bivajo, ne glede na to, kaj je zanju značilno (na primer, kako je okolica urejena, kako veliko je stanovanje, kako je ohranjeno). $\mathrm{V}$ zvezi s tem je zanimiva zlasti longitudinalna raziskava, o kateri poročajo William M. Rohe in Michael Stegman (1994) ter William M. Rohe in Victoria Basolo (1997). Raziskava namreč kaže, da je bil pri novih lastnikih nepremičnin po njenem nakupu zaznan statistično pomemben porast zadovoljstva z življenjem $\mathrm{v}$ primerjavi $s$ tistimi, ki so ostali v najemnem odnosu. Isti lastniki so višjo stopnjo zadovoljstva izrazili tudi tri leta pozneje, ne glede na to, da so bile njihove nepremičnine v manj zaželenih soseskah, kar so do takrat tudi že izkusili. William M. Rohe idr. (2001) navajajo, da so značilnosti stanovanja in bivalne okolice v okviru raziskav o ugotavljanju zadovoljstva upoštevali tudi drugi (na primer Morris idr., 1976; Kinsey in Lane, 1983; Varady, 1983; Lam, 1985; Danes in Morris 1986). V vseh primerih se je izkazalo, da so lastniki v primerjavi z najemniki z bivanjem bolj zadovoljni.

V skladu s pričakovanji in spoznanji drugih se tudi v našem primeru potrjuje, da so statistično pomembne razlike navezanosti med starejšimi glede na lastništvo nepremičnine, $\mathrm{v}$ kateri bivajo, in sicer $\mathrm{v}$ primeru navezanosti na stanovanje $(t(907)=$ $2,353, p=0,019)$. Lastniki so v povprečju svojo navezanost na stanovanje ocenili z oceno 4,42 - to je tudi najvišja povprečna ocena med vsemi vidiki navezanosti in zadovoljstva med lastniki -, najemniki pa s 3,89. Razlike v povprečnih ocenah se kažejo tudi v navezanosti na okolje in nekaterih vidikih zadovoljstva - na primer pri vseh treh vidikih zadovoljstva $s$ stanovanjem (velikost, razporeditev prostorov in gradbena kakovost) in v primeru miru v okolju ter bližine sorodnikov in prijateljev. Čeprav teh razlik ne moremo statistično dokazati, so enako kot pri navezanosti na stanovanje $\mathrm{v}$ vseh navedenih primerih večje zadovoljstvo in navezanost izrazili lastniki.

Ker so lahko starejši pri anketiranju izrazili tudi svoje mnenje oziroma so lahko svoje odgovore argumentirali, anketarji pa so jih zapisali, smo pri anketiranju poleg kvantitativnih podatkov pridobili tudi nekatere kvalitativne informacije. Med njimi je tudi mnenje, da so vprašani večinoma izredno navezani na svojo hišo, in sicer naj bi bili navezani celo bolj kot na stanovanje, saj so večinoma sodelovali pri gradnji, $\gg \mathrm{Z}$ velikim odrekanjem in trdim, lastnim delom «, kot so se pogosto izrazili. V socialističnem obdobju je bila namreč v Sloveniji značilna 
visoka stopnja samogradenj. To je razvidno tudi iz razmerja med lastništvom stanovanj in hiš med anketiranimi - lastnikov hiš je namreč $74,8 \%$, lastnikov stanovanj pa $25,2 \%$. Da bi preverili opažanja anketarjev, smo opravili podrobnejšo statistično analizo in ugotovili, da so lastniki hiš res izkazali statistično značilno višjo stopnjo navezanosti v primerjavi z lastniki stanovanj $(t(887)=2,633, p=0,009)$. Prvi so navezanost $\mathrm{v}$ povprečju ocenili s 4,46, drugi pa s 4,28. To ugotovitev lahko potrdimo tudi na podlagi enega od drugih vprašanj v anketi, pri katerem so lastniki hiš v primerjavi z lastniki stanovanj višje ocenili pomen, ki ga ima njihov dom za njih - da jim pomeni dosežek v njihovem življenju, so namreč lastniki hiš ocenili s povprečno oceno 4,14 (od pet), lastniki stanovanj pa s 3,91. Razlika med povprečnima ocenama obeh skupin je statistično pomembna pri petodstotnem tveganju $(t(876)=2,897, p=$ $0,004)$. Še precej večje in prav tako statistično pomembne razlike glede pomena doma so med lastniki in najemniki, in sicer so lastniki pomen doma ocenili s 4,08, najemniki pa z 2,84.

\section{Sklep}

Kot poudarja Golant (1982), domače bivalno okolje predstavlja starejšemu človeku velik del njegove celostne življenjske poti. Po Vasari (2015: 59) mu zato pomeni »več kot le stanovanje, zapolnjeno z osebnimi pomeni «. Ni naključje, da gojijo starejši ljudje do svojega doma pogosto zelo globoka čustva - nanj so navezani, $\mathrm{z}$ bivanjem v njem pa so (pogosto prav zaradi te navezanosti) zadovoljni. Spoznanja številnih strokovnjakov o navezanosti starejsih na domače bivalno okolje in o zadovoljstvu z njim smo proučili tudi v naši raziskavi. Zanimalo nas je, ali so starejši ljudje v Sloveniji navezani na svoj dom in ali so z njim zadovoljni, kako intenzivni sta stopnji navezanosti in zadovoljstva ter ali se starejši ljudje glede tega razlikujejo glede na starost, trajanje bivanja, tip naselja, v katerem bivajo, ter glede na lastništvo stanovanja. Skladno s pričakovanji se je potrdilo, da so starejši tudi pri nas v splošnem na svoj dom zelo navezani, da so z bivanjem v njem zelo zadovoljni in da se glede tega med seboj razlikujejo. In sicer so na svoj dom bolj navezani tisti, ki so starejšì, ki v svojih bivalnih okoljih bivajo že dalj časa, ki živijo na podeželju in ki so lastniki svojega stanovanja. Tudi pri posameznih vidikih zadovoljstva z ožjim in širšim bivalnim okoljem se kažejo med starejšimi razlike, vendar ne pri vseh vidikih. Tako se na primer pri zadovoljstvu z bivalnim okoljem v odnosu s trajanjem bivanja v njem kažejo med starejšimi razlike le pri zadovoljstvu z gradbeno kakovostjo in mirom v okolju, in sicer so tisti, ki bivajo v svojem stanovanju manj časa, z njegovo gradbeno kakovostjo in mirom v okolju bolj zadovoljni v primerjavi s tistimi, ki bivajo tam že dalj časa. Pri lastništvu se je pokazalo, do so razlike pri vseh treh vidikih zadovoljstva $s$ stanovanjem (velikost, razporeditev prostorov in gradbena kakovost) in v primeru miru v okolju ter bližine sorodnikov in prijateljev - v vseh primerih so večje zadovoljstvo izrazili lastniki -, vendar teh razlik ne moremo statistično dokazati. V okviru tipa naselja se stareǰ̌i, ki živijo v podeželskih naseljih, in tisti, ki živijo v mestih, ne razlikujejo po vidikih stanovanja in vidikih, povezanih s fizično dostopnostjo v okolju, razlikujejo pa se po zadovoljstvu z bližino storitev in oskrbe ter po zadovoljstvu z okoljem - v skladu s pričakovanji so z bližino storitev in oskrbe bolj zadovoljni starejši prebivalci mestnih naselij, z okoljem pa prebivalci podeželskih naselij. V okviru starosti so se razlike med vprašanimi pokazale pri vseh vidikih zadovoljstva, pri čemer se zadovoljstvo s stanovanjem in bivalnim okoljem po pričakovanjih s starostjo povečuje.

Čeprav so torej statistične analize pokazale, da so med starejšimi glede navezanosti in zadovoljstva $\mathrm{z}$ lastnim bivalnim okoljem statistično pomembne razlike, je treba (še enkrat) poudariti, da so starejši na dom zelo navezani in da so z njim tudi zelo zadovoljni ter da se v večini primerov kažejo le razlike med veliko in še večjo navezanostjo oziroma večjim in še večjim zadovoljstvom. Starejšim ljudem je treba zato zagotoviti, da ostanejo čim dalj časa v svojem domačem okolju. Bivanje v lastnem domu ima namreč zaradi zadovoljstva z njim in navezanosti nanj številne pozitivne učinke, zlasti na dobro počutje in psihofizično kondicijo starejših ljudi. Kot navajajo Jordana L. Maisel idr. (2008), so študije pokazale, da samostojno življenje spodbuja uspešno staranje $\mathrm{z}$ izboljšanjem zdravja, življenjsko zadovoljstvo in povečuje samozavest starejših, kar lahko časovno odloži prehod starejših v institucionalno obliko bivanja. Staranje domá (ang. ageing at home) oziroma staranje v domačem bivalnem okolju (ang. ageing in place) je zato najbolj zaželena oblika stanovanjskega varstva oziroma bivanja starejših. Preference starejših po bivanju v lastnem domu nimajo le pozitivnih strani, prinašajo tudi številne ovire, kot so (a) neustrezna ureditev stanovanja za bivanje starejših (na primer neustrezna kopalniška oprema, pragovi in druge arhitekturne ovire), (b) otežen dostop do stanovanja (na primer stopnice in večnadstropne stavbe brez dvigal), (c) neustrezna lokacija bivališča (na primer oddaljenost do javnih storitev in neustrezne prometne povezave, zaradi česar postanejo starejši ljudje čedalje bolj izolirani, pogosteje ostajajo v svojem stanovanju in so glede opravljanja storitev odvisni od pomoči drugih), (d) vzdrževanje stanovanja $\mathrm{v}$ primeru lastništva ter pokrivanje tekočih in letnih stroškov, ki so vezani na stanovanje. V takih primerih postane navezanost na dom čustveno, fizično in finančno breme. Vendar se starejši ljudje prav zaradi navezanosti ne želijo preseliti - to namreč dojemajo kot travmatično doživljanje (glej na primer Kerbler, 2012) - zato kljub slabi kakovosti bivanja in nezadovoljstvu vztrajajo v svojem domu, čeprav bi se jim lahko s preselitvijo v drugo bivalno okolje kakovost življenja izboljšala. 
Prav razumevanje odnosa starejših do preselitve bo tema nadaljnjih analiz v okviru naše raziskave. Še podrobneje bo treba analizirati tudi druge dejavnike, po katerih se starejši ljudje razlikujejo glede navezanosti na svoje domače bivalno okolje in glede zadovoljstva z njim (na primer ekonomsko stanje, vzdrževanost stanovanja, izobrazba ipd.), s poglobljenimi statističnimi metodami (na primer faktorsko analizo, multiplo regresijo) pa bo treba ugotoviti tudi medsebojno odvisnost dejavnikov, ki smo jih tokrat analizirali ločeno, oziroma njihovo součinkovanje pri vplivu na navezanost in na zadovoljstvo.

\section{Boštjan Kerbler}

Urbanistični inštitut Republike Slovenije, Ljubljana, Slovenija

E-naslov: bostjan.kerbler@uirs.si

Richard Sendi

Urbanistični inštitut Republike Slovenije, Ljubljana, Slovenija

E-naslov: richard.sendi@uirs.si

\section{Maša Filipovič Hrast}

Univerza v Ljubljani, Fakulteta za družbene vede, Ljubljana, Slovenija E-naslov: masa.filipovic@fdv.uni-lj.si

\section{Opombe}

${ }^{[1]} V$ članku uporabljamo za stanovanje in hišo splošen izraz stanovanje. Izjema je le zadnji del podpoglavja 4.4, vendar je v tem primeru razlikovanje med stanovanjem kot splošnim pojmom za stanovanjsko enoto in izrazoma stanovanje oziroma hiša natančno navedeno.

[2] Petstopenjska Likertova lestvica je urejenostna (ordinalna), vendar v znanstveni literaturi glede tega, ali jo lahko obravnavamo kot razmernostno oziroma intervalno, ni poenotenega mnenja (glej na primer Jamieson, 2004; Norman, 2010). Ker je v družboslovju zaradi prevladujočih mnenjskih lestvic ordinalna merska lestvica najpogostejša, lahko po priporočilih Centra za družboslovno informatiko (2017) s predpostavko, da so razlike med kategorijami enake, $v$ primeru ordinalne merske lestvice računamo povprečja in varianco, $\mathrm{s}$ čimer jo približamo intervalni merski lestvici.

\section{Zahvala}

Zahvaljujemo se Agenciji Republike Slovenije za raziskovalno dejavnost za financiranje temeljnega raziskovalnega projekta Inovativne oblike bivanja za starejše ljudi v Sloveniji, ki je potekal med letoma 2014 in 2017 pod šifro J5-6824. V projekt sta bila vključena Urbanistični inštitut Republike Slovenije in Fakulteta za družbene vede. Zahvaljujemo se tudi Karini Sirk, študentki Fakultete za družbene vede, za pomoč pri zbiranju in analizi literature.

\section{Viri in literatura}

Allardt, E. (1993): Having, loving, being: An alternative to the Swedish model of welfare research. V: Nussbaum, M., in Sen, A. (ur.): The quality of life, str. 88-94. Oxford, Clarendon Press.

DOI: 10.1093/0198287976.003.0008
American Association of Retired People (2000): Fixing to stay: A national survey of housing and home modification issues. Washington DC, Matthew Greenwald and Associates.

Anton, C. E., in Lawrence, C. (2014): Home is where the heart is: The effect of place of residence on place attachment and community participation. Journal of Environmental Psychology, 40, str. 451-461. DOI: 10.1016/j.jenvp.2014.10.007

Atkinson, T., Cantillon, B., Marlier, E., in Nolan, B. (2002): Social indicators. The EU and social inclusion. Oxford, Oxford University Press. DOI: 10.1093/0199253498.001.0001

Barlow, J., in Duncan, S. (1994): Success and failure in housing provision. European systems compared. Oxford, Pergamon Press.

Bonaiuto, M., Aielllo, A., Perugini, M., Bonnes, M., in Ercolani, A. P. (1999): Multidimensional perception of residential environment quality and neighbourhood attachment in the urban environment. Journal of Environmental Psychology, 19(4), str. 331-352. DOI: 10.1006/jevp.1999.0138

Boškić, R. (2002): Krepitev moči na stanovanjskem področju. V: Mandič, S., in Filipovič, M. (ur.): Stanovanjske študije, str. 21-43. Ljubljana, Univerza v Ljubljani, Fakulteta za družbene vede.

Bricker, K. S., in Kerstetter, D. L. (2000): Level of specialisation and place attachment: An explanatory study of Whitewater recreationists. Leisure Sciences, 20(4), str. 233-257.

Brown, G., in Raymond, C. (2007): The relationship between place attachment and landscape values: Towards mapping place attachment. Applied Geography, 27(2), str. 89-111. DOI: 10.1016/j.apgeog.2006.11.002

Case, D. (1996): Contributions of journeys away to the definition of home: An empirical study of a dialectical process. Journal of Environmental Psychology, 16(1), str. 1-15. DOI: 10.1006/jevp.1996.0001

Center za družboslovno informatiko (2017): Celovita podpora anketnemu procesu. Ljubljana, Univerza v Ljubljani, Fakulteta za družbene vede. Dostopno na: www.1 ka.si (sneto 17. 5. 2017).

Christenson, J. A. (1979): Urbanism and community sentiment: Extending Wirth's model. Social Science Quarterly, 60(3), str. 387-400.

Clough, R., Leamy M., Miller, V., in Bright, L. (2004): Housing decisions in later life. Basingstoke, UK, Palgrave/Macmillan.

Costa-Font, J. (2013): Housing related well-being in older people: The impact of environmental and financial influences. Urban Studies, 50(4), str. 657-673. DOI: 10.1177/0042098012456247

Czischke, D., in Gruis, V. (2007): Managing social rental housing in the EU in a changing policy environment: Towards a comparative study. Prispevek je bil predstavljen na seminarju z naslovom European Network for Housing Research Seminar, ki je potekal v Dublinu na Irskem od 20. do 21. aprila. Tipkopis.

Daly, H. E. (2007): Ecological economics and sustainable development: Selected essays of Herman Daly. Cheltenham, UK, Edward Elgar Publishing Limited. DOI: 10.4337/9781847206947

Danes, S., in Morris, E. (1986): Housing status, housing expenditures and satisfaction. Housing and Society, 13(1), str. 32-43.

DOI: $10.1080 / 08882746.1986 .11429976$

de Jong, P., Rouwendal, J., Van Hattum, P., in Brouwer, A. (2012): Housing preferences of an ageing population. Investigation in the diversity among Dutch older adults. Tilburg, Netspar.

Doling, J. (1999): Housing policies and the little tigers: How do they compare with the other industrialised countries? Housing Studies, 14(2), str. 229-250. DOI: 10.1080/02673039982939 
Doling, J. (2006): A European housing policy? European Journal of Housing Policy, 6(3), str. 335-349. DOI: 10.1080/14616710600973169

Domanski, H., Ostrowska, A., Przybysz, D., Romaniuk, A., in Krieger, H. (2006): First European quality of life survey. Social dimensions of housing. Dublin, Europen Foundation for Improvment of Living and Working Conditions.

Driscoll, M. (2011): Attachment to place: Individual differences in a house becoming a home. Doctoral thesis. Kent, Kent State University College and Graduate School of Education, Health, and Human Services.

Dupuis, A., in Thorns, D. C. (1996): Meanings of home for older homeowners. Housing Studies, 11(4), str. 485-501.

DOI: $10.1080 / 02673039608720871$

Erikson, R. (1993): Description of inequaity. The Swedish approach to welfare research. V: Craven Nussbaum, M., in Sen, K. A. (ur.): The qualiy of life, str. 67-83. Oxford, Oxford University Press. DOI: 10.1093/0198287976.003.0006

Fahey, T., Nolan, B., in Maitre, B. (2004): Housing expenditure and income povery in EU countries. Journal of Social Policy, 33(3), str. 437-454. DOI: $10.1017 /$ S0047279404007767

Field, A. (2009): Discovering statistics using IBM SPSS statistics. London, SAGE Publications Ltd.

Fischer, C. S. (1972): Urbanism as a way of life: A review and an agenda. Sociological Methods \& Research, 1(2), str. 187-242. DOI: $10.1177 / 004912417200100203$

Fogel, B. S. (1992): Psychological aspects of staying at home. Generations, 16(3), str. 15-19.

Fried, M. (2000): Continuities and discontinuities of place. Journal of Environmental Psychology, 20(3), 193-205. DOI: 10.1006/jevp.1999.0154

Galster, G. C. (1987): Homeowners and neighborhood reinvestment. Durham, NC, Duke University Press.

Gilleard, C., Hyde, M., in Higgs, P. (2007): The impact of age, place, aging in place, and attachment to place on the well-being of the over 50s in England. Research on Aging, 29(6), str. 590-605. DOI: $10.1177 / 0164027507305730$

Golant, S. M. (1982): The residential location and spatial behaviour of the elderly. Chicago, University of Chicago Press.

Hansen, E. B., in Gottaschalk, G. (2006): What makes older people consider moving house and what makes them move? Housing, Theory and Society, 23(1), str. 34-54. DOI: 10.1080/14036090600587521

Harris, P. B., Werner, C. M., Brown, B. B., in Ingebritsen, D. (1995): Relocation and privacy regulation: A cross-cultural analysis. Journal of Environmental Psychology, 15(4), str. 311-320. DOI: 10.1006/jevp.1995.0027

Hårsman, B., in Quigley, J. M. (1991): Housing markets and housing institutions: An international comparison. Boston, Kluwer Academic Publishing. DOI: 10.1007/978-94-011-3915-1

Hay, R. (1998): Sense of place in developmental context. Journal of Environmental Psychology, 18(1), str. 5-29. DOI: 10.1006/jevp.1997.0060

Hernandez, B., Hidalgo, M. C., in Ruiz, C. (2013): Theoretical and methodological aspects of research on place attachment. V: Manzo, L., in Devine-Wrights, P. (ur.): Place attachment: Advances in theory, methods and applications, str. 125-137. London, Routledge.

Heywood, F., Oldman, C., in Means, R. (2002): Housing and home in later life. Buckingham, UK, Open University Press.

Hidalgo, M. C., in Hernandez, B. (2001): Place attachment: Conceptual and empirical questions. Journal of Environmental Psychology, 21(3), str. 273-281. DOI: 10.1006/jevp.2001.0221
Hwang, S., Fuller-Thomson, J. D., Bryant, T., Habib, W., in Regoeczi, W. (1999): Housing and population health: a review of the literature. Ottawa, Mortgage and Housing Corporation.

Jamieson, S. (2004): Likert scales: How to (ab)use them. Medical Education, 38(12), str. 1217-1218. DOI: 10.1111/j.1365-2929.2004.02012.x

Jorgenson, B. S., in Stedman, R. C. (2001): Sense of place as an attitude: Lakeshore owners attitudes towards their properties. Journal of Environmental Psychology, 21, str. 233-248. DOI: 10.1006/jevp.2001.0226

Kasarda, D. J., in Janowitz, M. (1974): Community attachment in mass society. American Sociological Review, 39(3), str. 328-339. DOI: $10.2307 / 2094293$

Kerbler, B. (2012): Ageing at home with the help of information and communication technologies. Acta Geographica Slovenica, 52(1), str. 165-188. DOI: 10.3986/AGS52107

Kerbler, B. (2014): Housing for the elderly in Slovenia: Analysis of the most common forms. Theoretical and Empirical Researches in Urban Management, 9(2), str. 87-103.

Kinsey, J., in Lane, S. (1983): Race, housing attributes, and satisfaction with housing. Housing and Society, 10(3), str. 98-116. DOI: 10.1080/0888 2746.1983.11429932

Kleinman, M., Matznetter, W., in Stephens, M. (ur.) (1998): European integration and housing policy. London, Routledge.

Kyle, G., Graefe, A., in Manning, R. (2005): Testing the dimensionality of place attachment in recreational settings. Environment and Behavior, 37(2), str. 153-177. DOI: 10.1177/0013916504269654

Kyle, G., Theodori, G. L., Absher, J. D., in Jun, J. (2010): The influence of home and community attachment on firewise behaviour. Society and Natural Resources, 23, str. 1-18. DOI: 10.1080/08941920902724974

Lalli, M. (1992): Urban-related identity: Theory, measurement and empirical findings. Journal of Environmental Psychology, 12(4), str. 285-303. DOI: 10.1016/S0272-4944(05)80078-7

Lam, J. (1985): Type of structure, satisfaction and propensity to move. Housing and Society, 12(1), str. 32-44.

DOI: 10.1080/08882746.1985.11429958

Leckie, S. (1994): Towards an international convention on housing rights: Options at Habitat II. Washington, DC, American Society of International Law.

Lewicka, M. (2005): Ways to make people active: The role of place attachment, cultural capital, and neighbourhood ties. Journal of Environmental Psychology, 25(4), str. 381-395. DOI: 10.1016/j.jenvp.2005.10.004

Lewicka, M. (2010): What makes neighbourhood different from home and city? Effects of place scale on place attachment. Journal of Environmental Psychology, 30(1), str. 35-51. DOI: 10.1016/j.jenvp.2009.05.004

Lewicka, M. (2011): Place attachment: How far have we come in the last 40 years? Journal of Environmental Psychology, 31(3), str. 207-230. DOI: 10.1016/j.jenvp.2010.10.001

Lichter, D. L., in Brown, D. L. (2011): Rural America in an urban society: Changing spatial and social boundaries. Annual Review of Sociology, 37(1), str. 565-592. DOI: 10.1146/annurev-soc-081309-150208

Maisel, J., Smith, E., in Steinfeld, E. (2008): Increasing home access: Designing for visitability. Washington, DC, Center for Inclusive Design and Environmental Access.

Mandič, S. (1996): Stanovanje in država. Ljubljana, Znanstveno in publicistično središče.

Mandič, S. (2011): Stanovanje in blaginja starejših: primerjava Slovenije z izbranimi evropskimi državami. V: Mandič, S., in Filipovič Hrast, 
M. (ur.): Blaginja pod pritiski demografskih sprememb, str. 85-105. Ljubljana, Univerza v Ljubljani, Fakulteta za družbene vede.

Mandič, S. (2015): Stanovanjske razmere in mobilnost starejšega prebivalstva - Slovenija v primerjalni perspektivi. V: Majcen, B., in Mašič, S. (ur.): Značilnosti starejšega prebivalstva v Sloveniji - prvi rezultati, str. 183-195. Ljubljana, Inštitut za ekonomska raziskovanja.

Marcuse, P. (1987): The other side of housing: Oppression and liberation. Stockholm, Almqvist and Wiksell International.

McCool, S. F., in Martin, S. R. (1994): Community attachment and attitudes toward tourism development. Journal of Travel Research, 32(3), 29-34. DOI: 10.1177/004728759403200305

Mesch, G. S., in Manor, O. (1998): Social ties, environmental perception, and local attachment. Environment and Behaviour, 30(4), str. 504-519. DOI: 10.1177/001391659803000405

Milligan, V. R. (2003): How different? Comparing housing policies and housing affordability consequences for low-income households in Australia and the Netherlands. Utrecht, Utrecht University.

Mishra, S., Mazumdar, S., in Suar, D. (2010): Place attachment and flood preparedness. Journal of Environmental Psychology, 30(2), str. 187-197. DOI: 10.1016/j.jenvp.2009.11.005

Moore, R. L., in Graefe, A. R. (1994): Attachment to recreation settings: The case of rail-trail users. Leisure Sciences, 16(1), str. 17-31. DOI: 10.1080/01490409409513214

Morris, E., Crull, S., in Winter, M. (1976): Housing norms, housing satisfaction and the propensity to move. Journal of Marriage and the Family, 38(2), str. 309-320. DOI: 10.2307/350390

Norman, G. (2010): Likert scales, levels of measurement and the "laws" of statistics". Advances in Health Science Education, 15(5), str. 625-632. DOI: 10.1007/s10459-010-9222-y

Raymond, C., Brown, G., in Weber., D. (2010): The measurement of place attachment: Personal, community, and environmental connections. Journal of Environmental Psychology, 30(4), 422-434.

DOI: 10.1016/j.jenvp.2010.08.002

Riger, S., in Lavrakas, P. J. (1981): Community ties: Patterns of attachment and social interaction in urban neighbourhoods. American Journal of Community Psychology, 9(1), str. 55-66. DOI: 10.1007/ BF00896360

Rohe, W. M., in Basolo, V. (1997): Long-term effects of homeownership on the self-perceptions and social interaction of lowincome persons. Environment and Behavior, 29(6), str. 793-819. DOI: $10.1177 / 0013916597296004$

Rohe, W. M., in Stegman, M. (1994): The impact of home ownership on the social and political involvement of low-income people. Urban Affairs Quarterly, 30(september), str. 152-172. DOI: $10.1177 / 004208169403000108$

Rohe, W. M., Van Zandt, S., in McCarthy, G. (2001): The social benefits and costs of homeownership: A critical assessment of the research. Washington, Joint Center for Housing Studies of Harvard University.

Rollero, C., in De Picolli, N. (2010): Does place attachment affect social well-being? Revue europeénne de psychologie appliquée, 60(4), str. 233238.

Rossi, P. H., in Weber, E. (1996): The social benefits of homeownership: Empirical evidence from national surveys. Housing Policy Debate, 7(1), str. 1-35. DOI: 10.1080/10511482.1996.9521212

Rowles, G. D. (1983): Place and personal identity in old age: Observations from Appalachia. Journal of Environmental Psychology, 3(4), str. 299-313. DOI: 10.1016/S0272-4944(83)80033-4
Rowles, G. D., in Ravdal, H. (2002): Aging, place, and meaning in the face of changing circumstances. V: Weiss, R. S., in Bass, S. A. (ur.): Challenges of the third age: Meaning and purpose in later life, str. 81-114. New York, Oxford University Press.

Rubenstein, R. L. (1989): The home environments of older people: A description of the psychosocial processes linking person to place. The Journal of Gerontology: Social Sciences, 44(2), str. 45-53. DOI: 10.1093/geronj/44.2.545

Salomon, E. (2010): Housing policy solutions to support aging in place. Washington, DC, American Association of Retired People Public Policy Institute.

Sampson, R. J. (1988): Local friendship ties and community attachment in mass society: A multilevel systemic model. American Sociological Review, 53(5), str. 766-779. DOI: 10.2307/2095822

Saunders, P. (1990): A nation of home owners. London, Unwin Hyman.

Saunders, P., in Williams, P. (1988): The constitution of the home. Housing Studies, 3(1), str. 81-91. DOI: 10.1080/02673038808720618

Sendi, R., Černič Mali, B., Jakoš, A., Filipović, M. (2003): Stanovanjske potrebe upokojencev in drugih starejših ljudi. Ljubljana, Urbanistični inštitut Republike Slovenije.

Shamai, S. (1991): Sense of place: An empirical measurement. Geoforum, 22(3), str. 347-358. DOI: 10.1016/0016-7185(91)90017-K

Simmel, G. (1950): The metropolis and mental life. V: Wolff, K. H. (ur.): The sociology of Georg Simmel, str. 409-424. New York, Free Press.

Somerville, P. (1997): The social construction of home. Journal of Architectural and Planning Research, 14(3), str. 225-245.

Stedman, R. C. (2006): Understanding place attachment among second home mobility and well-being. Journal of Social Issue, 38, str. 149-171.

Stokols, D., in Shumaker, S. A. (1982): The psychological context of residential mobility and well-being. Journal of Social Issues, 38(3), str. 149-171. DOI: 10.1111/j.1540-4560.1982.tb01776.x

Štuhec, J. I., in Fras, M. (2010): Različne oblike bivanja za tretjo generacijo. Kakovostna starost, 13(3), str. 3-15.

Tartaglia, S. (2012): Different predictors of quality of life in urban environments. Social Indicators Research, 113(3), str. 1045-1053. DOI: 10.1007/s11205-012-0126-5

Theodori, G. L., in Luloff, A. E. (2000): Urbanization and community attachment in rural areas. Society and Natural Resources, 13(5), str. 399-420. DOI: $10.1080 / 089419200403839$

Tönnies, F. (1887): Community and society: Gemeinschaft and Gesellschaft. New York, Harper \& Row.

Trentelman, C. (2009): Place attachment and community attachment: A primer grounded in the lived experience of a community sociologist. Society and Natural Resources, 22(3), str. 191-210. DOI: $10.1080 / 08941920802191712$

Tuan, Y. E. (1980): Rootedness versus sense of place. Landscape, 24, str. 3-8.

Varady, D. (1983): Determinants of residential mobility decisions. Journal of the American Planning Association, 49(2), str. 181-199. DOI: 10.1080/01944368308977063

Vasara, P. (2015): Not ageing in place: Negotiating meanings of residency in age-related housing. Journal of Aging Studies, 35, str. 55-64. DOI: 10.1016/j.jaging.2015.07.004

Wahl, H. W. (2003): Place attachment across the life span. V: Miller, J. R. Lerner, R. M., Schiamber, L. B., in Anderson, P. M. (ur.): Encyclopedia of human ecology, str. 569-572. Santa Barbara, CA, ABC-Clio, Inc. 
Wahl, H. W., in Gitlin, L. N. (2003): Future developments in living environments for older people in the U.S. and Germany: Potential and constraints. V: Schaie, K. W., Wahl, H. W., Mollenkopf, H., in Oswald, F. (ur.): Aging independently: Living arrangements and mobility, str. 281-301. New York, Springer.

Walsh, K., in Ward, P. (2013): Social exclusion and ageing in rural areas: Patterns and implications. Galway, Irish Centre for Social Gerontology.

Williams, D. R., in Vaske, J. J. (2003): The measurement of place attachment: Validity and generalizability of a psychometric approach. Forest Science, 49(6), str. 830-841.

Williams, D. R., Patterson, M. E., Roggenbuck, J. W., in Watson, A. E. (1992): Beyond the commodity metaphor: Examining emotional and symbolic attachment to place. Leisure Sciences, 14(1), str. 29-46. DOI: 10.1080/01490409209513155

Wirth, L. (1938): Urbanism as a way of life. American Journal of Sociology, 44(1), str. 1-24. DOI: 10.1086/217913 